\title{
ENHANCING TOURISM OFFER IN THE TISZA VALLEY THROUGH TOURISM ANIMATION
}

\author{
Ivkov-Dzigurski Andjelija ${ }^{A}$, Kosic Kristina ${ }^{A}$, Nadj Imre $^{A}$, \\ Dragin AleksandraA ${ }^{A}$ Vujicic Miroslav ${ }^{A}$, Mladenovski Milan ${ }^{A}$
}

Received: December 16, 2018| Accepted: March 5, 2019

DOI: 10.5937/ZbDght1901057|

\begin{abstract}
The wealth of natural and cultural resources makes the Municipality Žabalj convenient place to stay for tourists. Current tourism offer isn't at a satisfactory level. It should be developed in several ways, one of the ways is a tourist animation. Tourist animation implies active participation of tourist in various forms of tourism. Sports and recreational tourism, rural tourism, cultural tourism, hunting and fishing tourism are just some of the forms of tourism where it is possible to apply a tourist animation in the area of the Municipality of Zabalj.
\end{abstract}

Keywords: municipality Zabalj, tourism, tourist animation, river Tisza, sports and recreational activities

\section{INTRODUCTION}

The Municipality of Žabalj is situated in the South Bačka administrative district of the Autonomous Province of Vojvodina, the region known under the name Šajkaška. It covers the territory of $400 \mathrm{~km}^{2}$, or $1.9 \%$ of the total territory of Vojvodina. The municipality comprises four settlements: Žabalj - the municipality centre, Čurug, Đurđevo and Gospođinci. According to the 2011 Census, the total population in those settlements was 26,134 inhabitants.

The municipality of Žabalj stretches to the west from the river Tisa. It is surrounded by the municipalities of Bečej, Srbobran, Temerin, Novi Sad, and Titel, and to the east with neighbouring municipalities of Zrenjanin and Novi Bečej.

The tourism position of the Municipality of ZZabalj regarding the places of tourists' arrival is favourable due to the vicinity of the largest emissive tourist centre - Novi Sad and the largest town in Banat - Zrenjanin which is in the zone of daily tourist movements. In addition to already mentioned towns, there are also the towns of Bečej and

A University of Novi Sad, Faculty of Sciences, Department of Geography, Tourism and Hotel Management, Trg D.Obradovića 3, 21000 Novi Sad, Serbia. Contact: ivkova@gmail.com 
Novi Bečej positioned in daily and weekend tourist movements zones. The surrounding settlements of Zrenjanin, Bečej and Novi Bečej are identified as major tourism competitors of the Municipality of Žabalj with their natural and anthropogenic tourism values (Ignjatić, 2009), offering either the same or similar content to prospective tourists.

The advantages of the position are also the proximity of international transit, traffic and tourism routes: Beograd-Novi Sad, Zrenjanin-Novi Sad.

\section{NATURAL AND SOCIAL VALUES SIGNIFICANT FOR TOURISM}

The territory of the Municipality of Žabalj stretches across the loess terrace and alluvial plain of the river Tisa. In some parts of the municipality there are also remnants of the alluvial terrace.

The area of Žabalj is located at north latitudes $45^{\circ} 18^{\prime}$ and $45^{\circ} 32^{\prime}$ and belongs to the mild part of climate belt with four seasons and the unequal lengths of day and night.

Hydrography is the most significant and the most attractive natural factor for tourism together with flora and fauna on the territory of the Municipality of Žabalj.

The Tisa River is the bordering river in the municipality. Its course through the territory of the Municipality of Žabalj is $31 \mathrm{~km}$ long, whereas it was $63 \mathrm{~km}$ prior to the regulation. The Tisa River has been shortened for $32 \mathrm{~km}$ in this sector by the river regulation plans (Bukurov, 1983, 23).

The meander Stara Tisa is the largest meander on this river, $24 \mathrm{~km}$ long, about $100 \mathrm{~m}$ wide and 1 to $3 \mathrm{~m}$ deep (http://www.pzzp.rs/). It is positioned along the right river bank near Biserno Ostrvo between Bačko Gradište and Čurug. That location was proclaimed Stara Tisa Nature Park in 2008. The clear water is rich in fish species (pike, catfish, carp, etc.) and numerous bird species which found their habitat in the rich vegetation of the river banks. The place has extraordinary potential for water sports. Public Utility Company Komunalac from Bečej manages the park.

The meander Vrbica is the meander of the Tisa River, about $2 \mathrm{~km}$ long, situated in the southern part of agricultural district of Žabalj. It is a secluded area far from the asphalt road, rich in fish species, with abundant clear water, and represents an oasis for adventurous people. There are numerous salaš farms nearby that may be valorised. Moreover, there is the plan for building the eco-camp.

According to the latest Census in 2011, there were 26,134 inhabitants in the Municipality of Žabalj. When the settlements are observed individually, the numbers are the following: Žabalj has 9,161 inhabitants, Čurug has 8,166 inhabitants, Đurđevo has 5,092 inhabitants, and Gospođinci has 3,715 inhabitants.

Economic activity is performed through the activities of the following economic subjects: business organisations, entrepreneurs, and agricultural holdings.

The municipality of Žabalj consists of four settlements: Žabalj (the seat of the municipality), Čurug, Đurđevo, and Gospođinci. All four settlements have the characteristics of typical Pannonian type of settlements in Vojvodina. The streets are wide; the houses are facing the streets and have spacious backyards and gardens. The settlements have 
either rectangular of square foundations with centrally positioned rectangular squares surrounded by churches, schools, important institutions and shops.

\section{CHARACTERISTICS OF TOURISM IN THE MUNICIPALITY OF ŽABALJ}

Natural resources. The territory of The Municipality of Žabalj is abundant in water courses: the rivers Tisa, Mrtva Tisa, Jegrička and the canal network Danube-Tisa-Danube. The river Jegrička, apart from drainage process, supplies the irrigation system with water, whereas its lower basin is transformed into a highly productive fish pond, whose potential for fish production is still is underused.

Jegrička Nature Park, situated in the south of Bačka, with its unique living world, diversity of natural habitats and picturesque landscapes breathes life into the somewhat monotonous relief of the agricultural area. In 2005, with the aim of preventing the degradation process, the decision about the protection of Jegrička was reached and it was proclaimed the nature park, an exceptional natural asset, managed by Public Utility Company 'Vode Vojvodine' (Group of authors, 2008).

Cultural resources. There are numerous objects and localities on the territory of Žabalj municipality, which remind us of the lifestyles of the people who used to live in this area. There are seven churches in four settlements. The churches are mainly from the Baroque era and belong to three religions (four of them Orthodox, one Catholic, and two Greek-Catholic churches). This fact illustrates living in a multicultural environment through history up to the present day. Apart from sacred object there are important archaeological locations, as well as cultural institutions.

Cultural tourism events. There are about 20 events in the municipality of Žabalj during the year. Based on certain similarities, it is possible to divide them into several categories: religious (burning the log - badnjak, Vertep - costumed performance of nativity motives, Swimming for the Holy Cross, Village Patron Saint Day (Slava)), ethnographic (Žabalj Days, Not to Forget), wine related (Nights of Young Wine, New Wines of Potisje Region, etc.), musical (Frogville Fest, Đurđevo Open Heart) and gastronomic (Zlatni Kotlić - fish soup preparation festival, Škembijada - tripe cooking competition, Disnotor - traditional pig slaughter and meat processing).

\section{ANIMATION IN TOURISM}

Animation as a contemporary type of tourist offer represents its more developed form and raises awareness among tourism employees that the customers need more than mere sun, sea or fresh air. Modern tourists follow the principle "value for money" when selecting specific tourism destinations. In addition to the former key factors for selecting a destination, they take into account additional options, primarily fun and entertainment. Certain tourists assign crucial role to the possibility of education and acquiring new skills. Those tourist motives belong to animation in tourism, the branch 
that has a growing role and significance in the development, promotion and placement of tourist products of a certain destination.

According to the etymology of the word animation, tourism animation is most frequently defined as enhancing the tourist offer with various contents and encouraging tourists to actively participate in the offered contents (Ivkov Džigurski, 2012, 13-15).

Certainly, the aim of the tourist offer is to achieve the economic results; however, the human dimension of it must not be neglected. Definitely, animation is a branch which contributes to economic results achievement by realisation of its human dimension. Animation satisfies tourists' needs for change, socialisation, creating holiday culture, acquiring new knowledge and skills, as well as creating a habit of having an active holiday.

A lot of travel agents offer their travellers sightseeing tours in local communities, listening to folklore music, stories about history and tradition, cooking lessons and traditional feasts. Local guides contribute to such cultural experience sharing, which altogether forms a unique introduction to national culture and tradition in everyday life (Vuksanović at al, 2013, 134).

\section{POSSIBLE FORMS OF ANIMATION IN THE MUNICIPALITY OF ŽABALJ}

It is possible to develop animation in tourism on the territory of The Municipality of Žabalj based on the tourism potentials: sports-recreational tourism, rural tourism, cultural tourism, hunting and fishing tourism, and other tourism types such as ecotourism and wine tourism.

Animation in sports-recreational tourism. Animation in sports-recreational tourism should be understood as instructions for culture related trips and should be developed as support in three directions: revealing own personality, socialising with other tourists and socialising with the host and his country.

Animation in sports-recreational tourism in the municipality of Žabalj may be performed in a golf centre, swimming classes, rowing classes and in other water sports.

Golf Centre is situated on the right bank of the Tisa River on the territory of Žabalj municipality. It covers the area of 45 hectares, with the golf course with nine holes and 2,700 meters in length. The Centre facilities include beginner's golf course with nine fully equipped and arranged training areas. Club house has modern equipment intended mainly for golf club members and their families to take a break and refresh in a cosy atmosphere. There is also a mini bar, equipment rental service and terrace in the very heart of the Golf Centre. The course has all the necessary facilities to organise golf tournaments on the system of two nine-hole rounds.

Golf course was built according to world standards regarding the design, irrigation system (Hunter), grass mixtures, natural and artificial golf obstacles (ponds, sand obstacles, hedges, and biotope). The course is extremely attractive and requires maximum concentration and precision. All those who make their first golf strokes here will be able to play and compete on any golf course in the world. (www.golfklub.rs). 
Hangar with water access in Čurug was officially approved as the training centre of the Serbian Rowing Federation. It was built in 2008, funded by the Provincial Secretariat for sport and youth and the Serbian Rowing Federation.

The main aim of the rowing club "Čurug" is the popularisation of this sport primarily with school children and adolescents interested in spending time in the nature with their friends. That is the way of introducing people to nature, raising their awareness about protection and preservation of the environment which is the most important issue.

The example of animation in sports-recreational tourism would be based on short training to master basic golf rules. The aim of this animation would be to explain basic golf rules of the game to tourists who arrive to the golf centre for the first time. First, instructors would explain the origins of the golf game and its name. Second, the instructors would give theoretical introduction into the rules of the game. Third, the theoretical instructions would be applied in practice. The instructors help tourists about the game techniques including how to hold a golf club with a proper grip. After the tourists master the techniques, the tournament is organized for tourists to apply the acquired techniques. Finally, after the tournament ends and the winners are declared, the tourists visit Čurug and Botić vinery where they are introduced to the local wines and a wine tasting event is organized.

At first, this animation programme should be performed for younger tourists, e.g. students visiting the municipality of Žabalj. They will be most interested in this type of animation which would certainly meet their expectations.

Animation in rural tourism. Animation as a part of a holiday, within rural tourism, plays an important role, mainly because of the people who would like, while staying in the countryside, to experience the beauty of a specific lifestyle with all its advantages and the elements which, in modern times, can be found only in the country.

Regarding the animation in rural tourism on the territory of the Municipality of Žabalj, it is possible to realize it in Babin Salaš in Žabalj, and in Monikin Salaš in Đurđevo.

An example of the animation in rural tourism - a part of the Žabalj municipality is characterized by the rural landscape with several salaš farms, with Babin Salaš as the most significant for tourism. The aim of animation in this form of tourism is to familiarize tourists with this way of life. In Babin Salaš, it is possible to organize activities such as arranging flower beds, tending vegetable gardens, working in the plant nursery, apple picking, producing brandy, etc. It is possible to organize medicinal herbs harvesting, grass mowing, poultry feeding. Another important factor of this type of tourism is educating young people about old arts and crafts, tools and traditional activities.

This type of tourism animation can be offered to schoolchildren who could have oneday excursions to the farm. This would be the most interesting to the children coming from cities, who are not familiar with this way of life. The role of the animator would be assigned to the hosts, in this case, who would perform most of the activities thus presenting them to the children. The children could help them with the activities which are suitable for their age. 
Tourist market is facing a problem of inadequate gastronomic offer for tourists who come from the parts of the world with different habits and needs regarding nutrition. It is extremely important to thoroughly instruct hospitality employees how to talk about food by getting them familiar with adequate dishes of various groups of customers (Cvetković at al., 2016).

Animation in cultural tourism. Regarding animation in cultural tourism on the territory of the Municipality of Žabalj, it is possible to realize it in the 7 sacred establishments in the municipal territory, mainly in the Church of the Ascension in Čurug. Tourists can be involved and animated in the mill called Rođina Vetrenjača. The visitors can learn about the culture of Ruthenians who live in Đurđevo, by presenting customs and rituals, with the active participation of tourists in conducting rituals.

Animation program in cultural tourism - the Ruthenians are the most numerous ethnic groups in the Žabalj municipality. As part of the cultural tourism animation, it is possible to present customs and the way of life of the Ruthenians, their national costumes, specific dishes and all their special characteristics. The main hosts are the members of the Culture and Art Society 'Taras Ševčenko' from Đurđevo, cherishing the Ruthenians heritage.

This form of tourist animation could be offered to groups of senior tourists, e.g. pensioners associations. Senior citizens are mostly interested in the culture and customs of other people and other nationalities. This program would foster socializing among pensioners from different places, who would also meet other cultures.

Animation in hunting and fishing tourism. Animation in hunting and fishing tourism is very specific, above all because of the special characteristics of the people participating in this form of tourism and on the other hand, because of the short trips in this form of tourism (1-4 days).

The territory of the Municipality of Žabalj features great potential for the development of hunting tourism. There are two hunting grounds: Stara Tisa with 40,000 ha and Ajlaš with 16,000 ha. The hunting grounds are of the lowland type along the river Tisa. The hunting ground is managed by the Hunting Association 'Srndać' from Žabalj, with their four branches in four settlements. The Association possesses five hunting lodges with the area of $560 \mathrm{~m}^{2}$, two hunting cabins with the area of $180 \mathrm{~m}^{2}, 20$ hectares of land and 324 hectares of thicket. Specialist service staff include the manager of the hunting ground and the hunting ground warden, who are helped by a group of 40 hunting ground volunteer wardens. The following are hunted: roe deer, rabbit, wild boar, pheasant, mallard, and quail.

The most favourable locations for fishing tourism and sport fishing are in the areas Vrbica - Žabalj and Mrtva Tisa - Biserno Ostrvo (Ahmetović-Tomka, 1996).

An example of animation in hunting and fishing tourism - regarding the fact that the Municipality of Žabalj has access to hunting grounds, as well as water streams rich with fish, it is possible to organize animation in hunting and fishing tourism.

Taking into account that this form of tourism requires certain maturity and physical fitness, tourism animation in hunting and fishing tourism should be aimed at adults. 
This type of tourism animation can be best used for tourists interested in hunting and fishing. This could include tourists who are members of hunting or fishing associations from other parts of Serbia, and from other countries.

For the purpose of organizing tourism activities, some facilities can be built: accommodation facilities, shooting ranges, canine dressage grounds, pheasant refuge, grounds for commercial hunting. The main accommodation facilities for the overnight stays and meals for hunters and the hunting ground employees are hunting lodges (Ponjiger at al., 2015), so at least one lodge per hunting ground should be built on the territory of the Municipality of Žabalj.

\section{Animation in other forms of tourism.}

Animation in eco-tourism - Eco-tourism is ecologically responsible travelling and visiting relatively preserved areas, for enjoying nature with the enhancement of nature protection, small negative impact of visitors and useful active impact on local population.

On the territory of the Municipality of Žabalj, animation in eco-tourism can be organized in 'Jegrička' Nature Park and 'Stara Tisa' Nature Park near Biserno Ostrvo. Here it is possible to organize walks for tourists around nature parks, as well as to educate tourists about plant and animal species in this location.

Animation in wine tourism. - According to Milosavljević and Jović, wine culture is the first and key element, without which there would be no wine tourism. Wine culture comprises certain knowledge on grapevine, its first appearance in the world and in our region, knowledge of the production basis of certain wine types, quality types of wine, serving wine, reading wine labels, wine temperature, wine glasses and wine and food pairing.

The Municipality of Žabalj has a great potential for the development of wine tourism. There is currently only one winery on the municipal territory - Botić Winery. This winery organizes the event the Nights of Young Wine in November. They also observe Saint Tryphon, the patron of wine and wine growers.

The latest event dedicated to wine is the event New Wines of Potisje, organized by the tourism organization of the Municipality of Žabalj. It is dedicated to the presentation of wines from this region.

\section{QUESTIONNAIRE SURVEY}

For the purpose of this research, a questionnaire was conducted to collect information on the current situation in tourism within the Municipality of Žabalj, which locations are mostly visited by the municipal residents, which forms of tourism have the greatest potential for further development. The respondents answered 12 questions which were in the survey. The first part of the survey are general questions about the respondents, such as their age, gender, profession, and the second part of the questionnaire refers to the personal attitudes of the respondents on the current and future situation in tourism in the Municipality of Žabalj, and if it is necessary to introduce tourism 
animation and in what form. The research sample consisted of 52 respondents. Questionnaire survey was conducted in all four settlements of the Municipality of Žabalj (Žabalj, Čurug, Đurđevo, Gospođinci).

\section{QUESTIONNAIRE SURVEY RESULTS}

The questionnaire involved 52 respondents, out of which 29 (55.77\%) were men, and 23 $(44.23 \%)$ women. The majority of respondents were in the age group from 26 to 40 , the total of 21 or $40.38 \%$, followed by the respondents younger than 25,16 of them, or in percentage $30.77 \%$. After them were the respondents in the age group 41 to 60,11 respondents, i.e. $21.16 \%$, and the least were respondents older than 60 , only four of them, i.e. $7.69 \%$. Regarding the educational structure of the respondents, the results are as follows: the most of the respondents are high school graduates, 27 of them (51.92\%), followed by college graduates with 6 respondents (11.54\%), there were 14 respondents who were university graduates, which is $26.92 \%$, and the least number of respondents had a master or doctoral degree, only 5 (9.62\%). Among the respondents, most of them are employed $30.49 \%$ (25 respondents), followed by students and pupils with $23.08 \%$ (12 respondents), unemployed $15.38 \%$ (8 respondents), four respondents said that they were farmers, which is $7.69 \%$, and three respondents said that they were homemakers with $5.77 \%$.

All respondents are the residents of the Municipality of Žabalj, out of which 19 of them (36.54\%) live in Žabalj, 26.92\%, i.e. 14 reside in Čurug, and 11 respondents (21.15\%) live in Đurđevo, whereas 15.36\% live in Gospođinci, i.e. 8 respondents.

In addition to resources that are characteristic for a certain location, there must be an adequate tourist offer so that tourists would be interested in visiting the place. One of the questions in the questionnaire asked if the respondents thought that the current tourist offer of the Municipality of Žabalj is adequate to attract sufficient number of tourists.

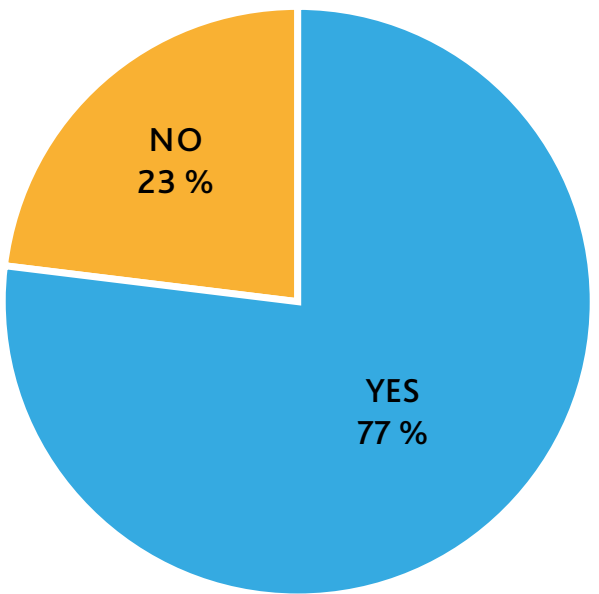

Figure 1. Potentials for further development of tourism Source: authors' survey results 


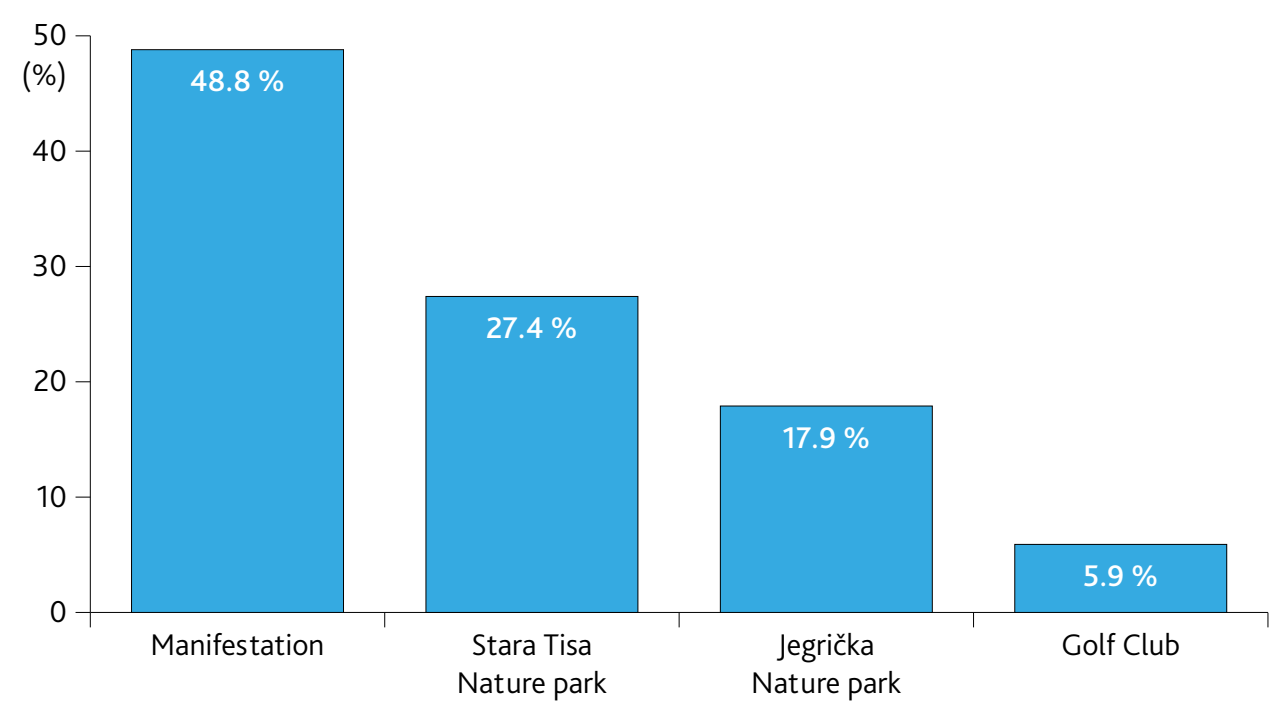

Figure 2. Major interests of the respondents

Source: authors' survey results

According to Figure 1, it can be seen that a large percentage of the respondents, i.e. the residents of the Municipality of Žabalj, think that their municipality has potentials for further development of tourism. Positive answers were given by 40 respondents, or $77 \%$, whereas 12 (23\%) respondents think that the Municipality of Žabalj does not have potentials for further development of tourism.

When asked which places they mostly visit on the municipal territory, the respondents mostly said that they go to events (41 of them), i.e. $48.81 \%$. Twenty three respondents $(27.38 \%)$ said that they most often visit 'Stara Tisa' Nature Park, followed by 'Jegrička' Nature Park with $17.86 \%$, which means that it was chosen by 15 respondents and only 5 respondents, making up to $5.81 \%$, said that they visit the golf centre.

When asked which types of tourism should be developed, in their opinion, in the Municipality of Žabalj, the respondents could circle more than one answer. The majority of respondents ( 39 or $37.50 \%$ ) think that rural tourism should be developed in the future in the Municipality of Žabalj. Secondly, sport and recreational tourism was chosen by 33 respondents (31.73\%), followed by cultural tourism with 19 respondents, or $8.27 \%$, event tourism was chosen by 14 respondents, or $13.46 \%$, followed by eco-tourism, chosen by 11 respondents (10.58\%) and according to the respondents, gastronomic tourism should be least developed, it was chosen by 7 respondents, or $6.73 \%$.

As it is shown in Figure 3, the majority of the respondents found that tourism animation for visitors is not present in the tourism offer of the Municipality of Žabalj, but that it should be, and this attitude is shared by $86.69 \%$ of the respondents. The total of $11.54 \%$ think that tourism animation is present, but it should be of better quality, whereas $5.77 \%$ think that animation is not present, but also that it should not be present, whereas no one said that animation is present at the highest level in the tourism offer of the Municipality of Žabalj. 


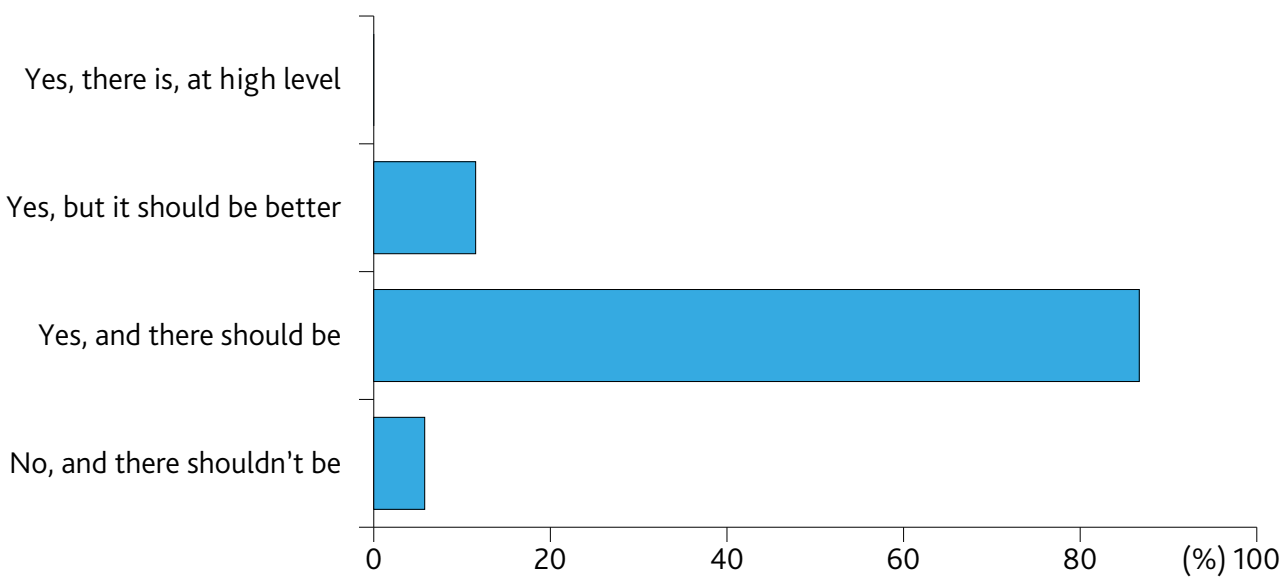

Figure 3. Availability of tourism animation for visitors

Source: authors' survey results

The respondents were also given a task to give a mark to the importance of tourism animation in certain forms of tourism on the scale from 1 to 5 , with the following values: mark 1- not important at all, 2 - partly unimportant, 3 - important and unimportant, 4 - partly important, 5 - completely important. The respondents gave the highest mark to rural tourism, because they think that tourism animation is extremely important in this segment, and the average mark for rural tourism was 4.8. Event tourism was given the average mark 4.5, sports and recreational tourism 3.9, gastronomic tourism 3.8 , whereas the respondents thought that tourism animation in eco-tourism is the least important, so this form of tourism was given the average mark 3.2.

\section{CONCLUSION}

The opinion of the respondents is that the current tourism offer is not adequate in order to attract tourists, and that the Municipality of Žabalj has potentials for the further development of tourism. Survey participants share the opinion that rural tourism should be developed first, as well as sports and recreational tourism on the water and land. They also think that tourism animation is not currently present in the tourism offer of the Municipality of Žabalj, but that it should be, as well as that the animation is mostly needed in the rural and event tourism.

In the following period, animation programmes for different market segments should be created, mainly different animation programmes for different age groups of tourists. It is not possible to apply the same programmes for children who come for the excursion or, for example, a group of pensioners who come for a tour. The programmes for children must be age appropriate and must involve the children to a certain extent, which goes for senior visitors as well, whereas the youth and the adults can be more actively involved in the animation programmes. 
Animation in different tourism segments on the municipal territory of Žabalj can contribute to the increased visitation to currently underdeveloped locations. Another benefit of tourism animation could be an increased tourist satisfaction, so tourists might return to experience animation in another tourism segment on offer in the Municipality of Žabalj. Furthermore, visitors would spend more in the non-accommodation segment, which would create new jobs for the local population.

\section{ACKNOWLEDGEMENT}

This research is part of the project INTERREG-IPA Cross-border Cooperation Programme Hungary - Serbia „Development of water tourism on waterways connecting Hungary and Serbia" (WATERTOUR; HUSRB/1602/31/0204) and Project no. 114-4512465/2018-02 (Funded by Provincial Secretariat for Higher Education and Science, Autonomous Province of Vojvodina, Republic of Serbia).

\section{REFERENCES}

Ahmetović-Tomka, D. (1996). Turistički potencijali Jegričke, Monografija Jegričke, Edicija Tija voda, Pčesa, Novi Sad.

Bukurov, B. (1983). Opština Žabalj, Prirodno-matematički fakultet u Novom Sadu, Institut za geografiju, Novi Sad.

Cvetković, B., Kalenjuk, B., Tešanović, D., Babić, M. (2016). Gastronomske potrebe savremenih turista kao problem turističkog tržišta. Zbornik radova Departmana za geografiju turizam i hotelijerstvo. 45-2, 117-131.

Grupa autora (2008). Zaštićena prirodna dobra i ekoturizam Vojvodine, Univerzitet u Novom Sadu, Prirodno-matematički fakultet, Departman za geografiju, turizam i hotelijerstvo, Novi Sad.

Ivkov Džigurski, A. (2012). Turistička Animacija, Univerzitet u Novom Sadu, Prirodnomatematički fakultet, Departman za geografiju, turizam i hotelijerstvo, Novi Sad.

Ignjatić, N. (2009). Turistička valorizacija pravoslavne crkve u Čurugu. Diplomski rad. Novi Sad: Univerzitet u Novom Sadu. Prirodno-matematički fakultet u Novom Sadu, Departman za geografiju, turizam i hotelijerstvo.

Ponjiger, I., Lulić D., Kovačević M., Marković V., Matejević M. (2015). Uticaj lovnog turizma na transformaciju prostora. Zbornik radova Departmana za geografiju turizam $i$ hotelijerstvo. 44-1, 96-114.

Vuksanović, N., Pivac, T., Dragin, A. (2013). Savremeni trendovi u nautičkom turizmu na primeru rečnih kompanija za krstarenje u Evropi. Zbornik radova Departmana za geografiju turizam i hotelijerstvo. 42, 125-141.

www.golfklub.rs

www.pzzp.rs 